\title{
ANALYSIS OF MUSCULOSKELETAL CHANGES IN PATIENTS WITH POSTURAL ROUNDBACK
}

\author{
ANÁLISE DAS ALTERAÇÕES MUSCULOESQUELÉTICAS DO PACIENTE COM DORSO CURVO POSTURAL \\ ANÁLISIS DE LAS ALTERACIONES MUSCULOESQUELÉTICAS EN PACIENTES CON DORSO \\ CURVO POSTURAL
}

Débora Pinheiro Lédio Alves¹, Vera lúcia dos Santos Alves'1, Osmar Avanzi ${ }^{1}$

\begin{abstract}
Objective: To analyze the clinical and radiographic changes in patients with postural rounded upper back. Methods: 30 patients diagnosed with postural rounded upper back were studied, being 22 male and eight female, aged between 10 and 20 years, referred by the outpatient clinic of the Grupo de Cirurgia da Coluna of the Irmandade da Santa Casa de Misericórdia de São Paulo, SP, Brazil. Patients underwent assessment of posture, special tests to check for muscle retractions and radiographic examination to measure the curvatures of spine using the Cobb method. Results/Conclusion: It is concluded that in the postural roundback there is a moderate increase of the thoracic kyphosis; the lumbar and cervical curvatures do not increase as a compensatory mechanism; the head appears anteriorized and the shoulder is also anteriorized and medially rotated; muscle retractions are present in the hamstrings, hip flexors, pectoralis minor and adductors of the shoulder muscles; the mobility of the lumbar spine is preserved and there is no relationship between the magnitude of thoracic curvature and the retraction of the hamstring muscles.
\end{abstract}

Keywords: Back; Kyphosis; Lordosis; Posture; Muscle, skeletal.

\begin{abstract}
RESUMO
Objetivo: Analisar as alterações clínicas e radiográficas do paciente com dorso curvo postural. Métodos: Foram estudados 30 pacientes com diagnóstico de dorso curvo postural, sendo 22 do sexo masculino e oito do feminino, com idades entre 10 e 20 anos, encaminhados pelo ambulatório do Grupo de Cirurgia da Coluna da Irmandade da Santa Casa de Misericórdia de São Paulo, SP, Brasil. Os pacientes foram submetidos à avaliação da postura, a testes especiais para verificar as retrações musculares e a exame radiográfico para mensurar as curvaturas da coluna vertebral pelo método de Cobb. Resultados/Conclusão: Concluímos que no dorso curvo postural existe um aumento moderado da cifose torácica; as curvaturas lombar e cervical não aumentam como mecanismo compensatório; a cabeça apresenta-se anteriorizada e os ombros anteriorizados e rodados medialmente; as retrações musculares estão presentes nos músculos isquiotibiais, flexores do quadril, peitoral menor e adutores do ombro; a mobilidade da coluna lombar está preservada e não existe relação entre a magnitude da curvatura torácica e a retração dos músculos isquiotibiais.
\end{abstract}

Descritores: Dorso; Cifose; Lordose; Postura; Musculoesquelético.

\section{RESUMEN}

Objetivo: Analizar las características clínicas y radiológicas del paciente con dorso curvo postural. Métodos: Se estudiaron 30 pacientes con diagnóstico de dorso curvado postural, siendo 22 hombres y ocho mujeres, con edades entre 10 y 20 años, encaminados por el ambulatorio del Grupo de Cirurgia da Coluna da Irmandade da Santa Casa de Misericórdia de São Paulo, SP, Brasil. Los pacientes se sometieron a la evaluación de la postura, pruebas especiales para detectar las retracciones musculares y examen radiográfico para medir las curvaturas de la columna vertebral por el método de Cobb. Resultados/Conclusiones: Se concluye que en el dorso curvado postural hay un aumento moderado de la cifosis torácica; las curvaturas lumbar y cervical no aumentan como mecanismo compensatorio; la cabeza se presenta anteriorizada y el hombro también es anteriorizado y con rotación medial; las retracciones musculares están presentes en los músculos isquiotibiales, flexores de la cadera, pectoral menor y aductores del hombro; la movilidad de la columna lumbar se conserva preservada y no hay relación entre la magnitud de la curvatura torácica y la retracción de los músculos isquiotibiales.

\section{Descriptores: Dorso; Cifosis; Lordosis; Postura; Musculoesquelético.}

\section{INTRODUCTION}

There are several changes of the locomotor apparatus in school-age children, among which we highlight retraction of the ischiotibial muscles and misalignment of the spine in the sagittal plane. Such changes occur mainly in stages of growth associated with a lack of adequate physical exercise, as this maintains sufficient muscular stretching and toning to protect the spine and proper body posture. ${ }^{1}$ The pre-puberty and puberty phases are periods in life when posture undergoes adjustment and adaptations, due not only to bodily changes, but also to psychological factors. $^{2}$

Intrinsic and extrinsic factors, such as heredity, the individual's physical and socioeconomic conditions, emotional factors, and physiological changes due to growth and bodily development, can all influence posture. In addition, habits and types of activity can affect posture. A child who is taller than their friends, or teased for being taller, takes on a posture of curved, down-turned shoulders, arching the back and neck to try and make themselves appear shorter.

1. Faculdade de Ciências Médicas, Irmandade da Santa Casa de Misericórdia de São Paulo, São Paulo, SP, Brazil.

Study conducted at the Department of Orthopedics and Traumatology of the Irmandade da Santa Casa de Misericórdia de São Paulo, São Paulo, SP, Brazil. Correspondence: Av. Cassiano Ricardo, 101, apt. 113 B, Jd. Aquarius, São José dos Campos, São Paulo, SP, Brasil. 12246870. debpfisio@gmail.com 
A teenager with overly large breasts tends to assume a posture bent towards the front in an attempt to hide them and in this way, molds a posture that can become permanent and persist for her whole life..$^{2,3}$

Among the various changes in the spine that can be present in childhood and adolescence, we highlight misalignment of the sagittal plane, in particular an increase in kyphosis, which is often neglected and called bad posture. Such an increase can be structural and important, as in the case of Scheuermann's kyphosis. ${ }^{3}$

Roundback is encountered in two clinical forms: postural and Scheuermann's kyphosis, also known as juvenile kyphosis. Both are often detected in adolescence., ${ }^{3,4}$ The postural form is represented by a moderate increase in self-correcting thoracic kyphosis and lumbar lordosis without muscle retractions or painful manifestations, and without radiographic evidence of any changes in the vertebral bodies or intervertebral discs. ${ }^{3-5}$ Radiographically, this deformity is characterized by an increase in the angle of thoracic kyphosis generally greater than $45^{\circ}, 3,6-10$

Scheuermann's kyphosis is represented by a marked increase in thoracic kyphosis accompanied by radiographic changes such as wedging of at least $5^{\circ}$ in one or more vertebrae, irregular end plates, and thinning of the intervertebral discs. Clinically, there is also evidence of increased compensatory lumbar and cervical lordosis, in addition to muscular contractions mainly of the ischiotibial and pectoral muscles. ${ }^{3-4,9}$

Several studies addressing Scheuermann's kyphosis and its clinical repercussions are found in the literature ${ }^{9-11}$ although little is known or described about postural roundback. The objective of this study is to evaluate the clinical and radiographic changes present in patients with postural roundback.

\section{CASE SERIES AND METHOD}

Thirty patients diagnosed with postural roundback, characterized by a clinical and radiographic increase in thoracic kyphosis of more than $45^{\circ}$, flexible, and without radiographic changes were included in the study. ${ }^{3,4,6}$ (Figure 1) The patients were between 10 and 20 years of age and were referred by the Spinal Surgery Group of the Department of Orthopedics and Traumatology of Faculdade de Ciências Médicas da Santa Casa de São Paulo (FCMSCSP). The project was approved by the Ethics Committee for research in humans of this institution, under no. 314/04.

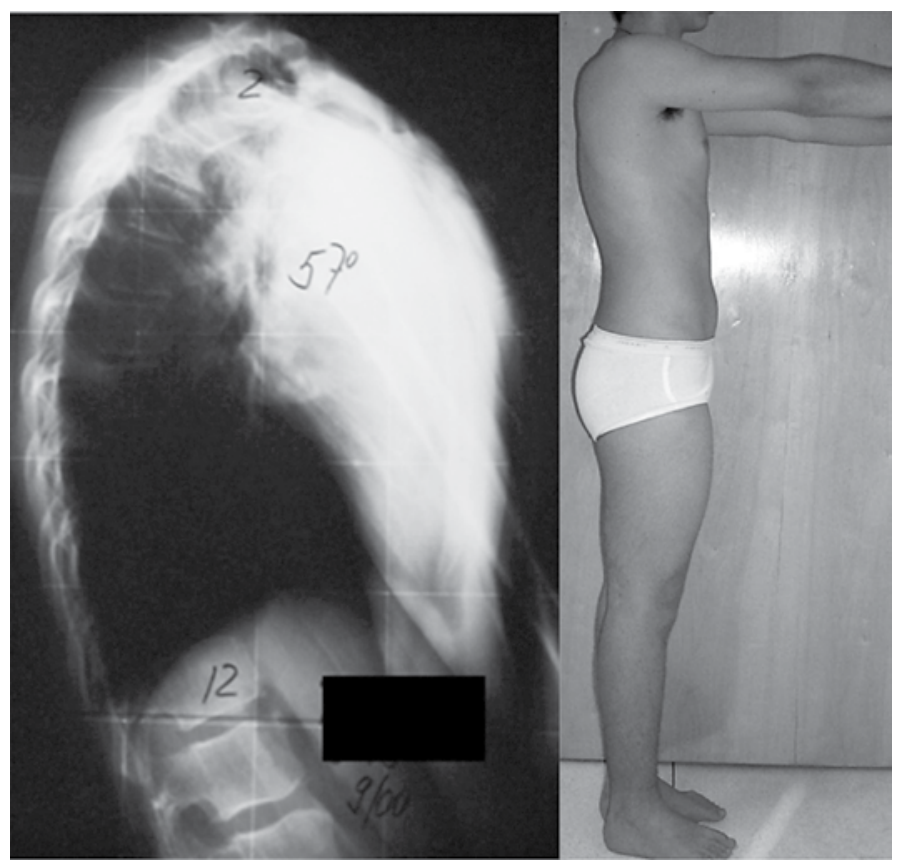

Figure 1. Radiographic and clinical evaluation of a patient with postural roundback.
Patients with roundback of other etiologies, or with diagnoses of postural roundback associated with respiratory diseases and/or orthopedic diseases of the lower limbs, or who had undergone any type of orthopedic or physical therapy treatment, were not included.

All patients were evaluated by means of physical and radiographic exams performed by the team physical therapist, an expert in spinal disorders with more than ten years of experience.

During the physical exam, an observational analysis of posture in the sagittal plane in the standing position was performed using a plumb line, as recommended by Kendall et al, ${ }^{12}$ as well as special tests to identify muscle retractions, such as the popliteal angle test, the Thomas test, the pectoralis major test, the pectoralis minor test, the shoulder adductor muscle test, the modified Shober test, and the toe-touch test.

To confirm the retraction of the ischiotibial musculature the popliteal angle test was used..$^{13}$ The test was performed with the patient in the supine position, with the hip of the limb to be tested flexed, the knee at a $90^{\circ}$ angle, and the contralateral limb extended. The knee to be tested was then passively extended until it met the first resistance. At this point, the angle was measured using a standard goniometer centered on the joint line. We consider a popliteal angle greater than $157^{\circ}$ to be normal, i.e. without retraction of the ischiotibial musculature. ${ }^{14,15}$

The Thomas test was used to evaluate retraction of the hip in flexion. With the patient lying down in the supine position, the examiner flexed the hips towards the trunk until the spine was flat on the examination table. The limb to be tested was then extended towards the table, while the other remained flexed up to the trunk. If the hip of the limb being tested was not totally extended, the test was considered positive and the angle formed between the table and the limb was measured using the goniometer, with the fixed arm parallel to the table and the mobile arm aligned with the femur. Otherwise, the measurement was logged as $0^{\circ} .12,13,16$

To identify retraction of the pectoralis major, pectoralis minor, and shoulder adductor muscles, the method described by Kendall et $\mathrm{al}^{12}$ was used.

For the pectoralis major test, the patient stayed in the supine position, with the knees flexed and the lumbar spine pressed against the table. The examiner positioned the upper limb of the patient at $90^{\circ}$ of abduction to test the upper fibers, and at $135^{\circ}$ for the lower fibers, keeping the elbow extended and the shoulder in lateral rotation. If the limb does not lie flat against the exam table, it is a sign of retraction and the distance from the lateral epicondyle to the table must be measured in centimeters using a tape measure. ${ }^{12}$

In the pectoralis minor test, the patient remained in the supine position, with the upper limbs at the sides, knees flexed, and the lumbar spine pressed against the table. The examiner stood at the head of the table and observed the position of the shoulders. When there is retraction, the shoulder will remain in a forward position and not lie flat against the examination table. ${ }^{12}$

For the exam of the shoulder adductor group (teres major, latissimus dorsi, and rhomboid), the patient remained in the supine position with the lower limbs flexed. The shoulders were flexed as wide as possible, keeping the lumbar spine pressed against the table. If there is retraction, the shoulder joint will not be completely flexed and the upper limbs will not lie flat against the table. This retraction is defined as the distance between the lateral epicondyle and the exam table, measured using a tape measure. ${ }^{12}$

The Shober test, modified by Macrae and Wright ${ }^{17}$ in 1969, was used with the aim of evaluating the flexibility of the lumbar spine. ${ }^{17-19}$ For the exam, the patient remained in a standing position and a point on the posterior superior iliac spine was marked with a pen. $A$ second mark was placed $10 \mathrm{~cm}$ above and a third five centimeters below it. The patient was asked to flex the trunk as far as possible, keeping the knees extended, and the distance between the second and third marks was measured. The difference between this measurement and the initial measurement corresponds to the flexibility of the lumbar spine. A result equal to or greater than seven centimeters is considered normal. ${ }^{17-18}$ 
The toe-touch test evaluates the flexibility of the spinal erector and ischiotibial muscles. In this test, the patient flexed the trunk trying to touch the ground with the tip of the middle finger, keeping the knees completely extended. The distance between the tip of the middle finger and the ground was measured with a tape measure. A value of up to $5 \mathrm{~cm}$ is considered normal. ${ }^{19-21}$

For the radiographic evaluation, a profile panoramic radiograph of the spine at a distance of 1.5 meters using $35 \times 91 \mathrm{~cm}$ film was taken. The patient remained in a standing position with the upper limbs elevated at $90^{\circ}$ assisted by a support and was instructed to keep the head erect and to look forward. The angles of cervical lordosis, thoracic kyphosis, and lumbar lordosis were measured by the Cobb method. ${ }^{22}$

Cervical lordosis was measured using the upper end plate of C2 and $\mathrm{C} 6$ as reference, adopting a value of $34^{\circ}$ as normal. ${ }^{23} \mathrm{~A}$ higher value was considered hyperlordosis, and a value lower than $5^{\circ}$ was considered to be rectified.

To measure thoracic kyphosis, the upper end plate of T3 and the lower end plate of $\mathrm{T} 12$ were used to define the parameter and a value between $20^{\circ}$ and $45^{\circ}$ was considered to be normal according to the Cobb method. ${ }^{6-8}$

Lumbar lordosis was measured using the upper end plate of $\mathrm{L} 1$ and the lower end plate of $\mathrm{L} 5$, and a value between $20^{\circ}$ and $60^{\circ}$ was considered normal. ${ }^{8,10}$

\section{Statistical Analysis}

The SPSS program (Statistical Package for Social Sciences) version 17.2 was used.

The Wilcoxon test was applied to evaluate possible differences between the right and left sides in the popliteal angle, Thomas test, and shoulder adductor muscles test and the Spearman's correlation analysis was used to confirm the relationship between the variables.

We adopted a significance level of $5 \%(a=0.050)$.

\section{RESULTS}

The sample evaluated in our study consisted of 30 patients: 22 males (73\%) and 8 females (27\%). The average age was 14 years and seven months $(\mathrm{SD}=$ two years and seven months).

In terms of postural changes in the sagittal plane, we found 29 patients with anteriorization of the head, 13 with the cervical region presenting hyperlordosis and 11 with normal positioning of the cervical region, 28 with anteriorized shoulders and internal rotation, 23 with lumbar hyperlordosis, 23 with pelvic anteversion and 20 with knees in the normal position. (Table 1)

In the evaluation of equality between the right and left sides of the popliteal angle, Thomas test, and shoulder adductor muscles test variables, we did not find any statistically significant differences between the sides, which made it possible to perform the statistical analysis using the average of the measurement values of the left and right sides.

The summary measurements and the respective confidence interval of the parametric variables, the tests to identify muscular retraction, and the radiographic exams are described in Table 2.

Regarding the frequency and percentage of cervical curvature in the radiographic exam, we found only 2 patients $(6 \%)$ with hyperlordosis, 27 patients (97\%) with hypolordosis, and one patient (3\%) within the normal range.

In the lumbar region, four patients (13\%) presented an increase in lumbar lordosis and 26 (87\%) were within the normal range. None of the patients exhibited hypolordosis.

We encountered muscular retraction in $93 \%$ of the patients in the popliteal angle test, $87 \%$ in the Thomas test, $97 \%$ in the pectoralis minor test, $93 \%$ in the shoulder adductor muscles test, $53 \%$ in the modified Shober test, and 93\% in the toe-touch test. (Table 3)

When we correlated the variables studied, the only statistically significant correlation ( $p=0.011$ and $r=0.456$ ) we found was between the modified Shober test and lumbar curvature.

We did not find a statistically significant correlation for any of the other variables in this study. (Table 4)
Table 1. Evaluation of posture in the sagittal plane: number of cases and percentages

\begin{tabular}{c|c|c|c}
\hline \multirow{2}{*}{ Region } & Position & Frequency & $\begin{array}{c}\text { Percentage } \\
(\mathbf{\%})\end{array}$ \\
\hline \multirow{3}{*}{ Head } & Anteriorized & 29 & 97 \\
\cline { 2 - 4 } & Normal & 1 & 3 \\
\hline \multirow{3}{*}{ Cervical } & Hyperlordosis & 13 & 43 \\
\cline { 2 - 4 } & Hypolordosis (rectified) & 6 & 20 \\
\cline { 2 - 4 } & Normal & 11 & 37 \\
\hline \multirow{3}{*}{ Shoulders } & Anteriorization and internal rotation & 28 & 93 \\
\cline { 2 - 4 } & Normal & 2 & 7 \\
\hline \multirow{3}{*}{ Lumbar } & Hyperlordosis & 23 & 77 \\
\cline { 2 - 4 } & Hypolordosis (rectified) & 2 & 7 \\
\cline { 2 - 4 } & Normal & 5 & 17 \\
\hline \multirow{3}{*}{ Pelvis } & Anteversion & 23 & 77 \\
\cline { 2 - 4 } & Retroversion & 2 & 7 \\
\cline { 2 - 4 } & Normal & 5 & 17 \\
\hline \multirow{2}{*}{ Right knee } & Hyperextension & 20 & 33 \\
\cline { 2 - 4 } & Normal & 10 & 33 \\
\hline \multirow{2}{*}{ Left knee } & Hyperextension & 20 & 67 \\
\cline { 2 - 4 } & Normal & &
\end{tabular}

Source: Department of Orthopedics and Traumatology of ISCMSP

Table 2. Descriptive measurements from the evaluation tests of muscular retraction and radiographic exams (in degrees)

\begin{tabular}{|c|c|c|c|c|c|c|c|}
\hline \multirow{2}{*}{ Variable } & \multirow{2}{*}{$\mathbf{n}$} & \multirow{2}{*}{ Minimum } & \multirow{2}{*}{ Maximum } & \multirow{2}{*}{ Average } & \multirow{2}{*}{$\begin{array}{l}\text { Standard } \\
\text { deviation }\end{array}$} & \multicolumn{2}{|c|}{$\begin{array}{c}\text { Confidence } \\
\text { interval }(95 \%)\end{array}$} \\
\hline & & & & & & \begin{tabular}{|c|} 
Lower \\
limit
\end{tabular} & $\begin{array}{l}\text { Upper } \\
\text { limit }\end{array}$ \\
\hline $\begin{array}{c}\text { Popliteal } \\
\text { angle test }\end{array}$ & 30 & 120 & 170 & 135 & 10 & 131 & 139 \\
\hline Thomas test & 30 & 0 & 23 & 10 & 5 & 8 & 12 \\
\hline $\begin{array}{c}\text { Shoulder } \\
\text { adductor } \\
\text { muscles } \\
\text { test }\end{array}$ & 30 & 0 & 13 & 6 & 3 & 5 & 8 \\
\hline $\begin{array}{c}\text { Modified } \\
\text { Shober test }\end{array}$ & 30 & 4 & 9 & 7 & 1 & 6 & 7 \\
\hline $\begin{array}{c}\text { Toe-touch } \\
\text { test }\end{array}$ & 30 & 0 & 35 & 16 & 8 & 13 & 19 \\
\hline $\begin{array}{c}\text { Cervical } \\
\text { curvature } \\
\end{array}$ & 30 & 0 & 38 & 17 & 11 & 13 & 21 \\
\hline $\begin{array}{l}\text { Thoracic } \\
\text { curvature }\end{array}$ & 30 & 46 & 74 & 57 & 8 & 54 & 60 \\
\hline $\begin{array}{l}\text { Lumbar } \\
\text { curvature }\end{array}$ & 30 & 29 & 74 & 48 & 11 & 43 & 52 \\
\hline
\end{tabular}

Source: Department of Orthopedics and Traumatology of ISCMSP.

Table 3. Description of the frequency and percentage of muscular retraction measured by special tests.

\begin{tabular}{c|c|c|c}
\hline Muscular retraction tests & $\mathbf{n}$ & Frequency & Percentage (\%) \\
\hline Popliteal angle test & 30 & 28 & 93 \\
\hline Thomas test & 30 & 26 & 87 \\
\hline Pectoralis major muscle test & 30 & 0 & 0 \\
\hline Pectoralis minor muscle test & 30 & 29 & 97 \\
\hline Shoulder adductor muscle test & 30 & 28 & 93 \\
\hline Modified Shober test & 30 & 16 & 53 \\
\hline Toe-touch test & 30 & 28 & 93 \\
\hline
\end{tabular}

Source: Department of Orthopedics and Traumatology of ISCMSP. 
Table 4. Correlation between thoracic curvature and other curvatures and muscular retraction tests using Spearman's correlation coefficient.

\begin{tabular}{c|c|c|c}
\hline Variable 1 & Variable 2 & $\begin{array}{c}\text { Correlation } \\
\text { coefficient }\end{array}$ & $\begin{array}{c}\text { Significance } \\
\text { (p) }\end{array}$ \\
\hline Thoracic curvature & Popliteal angle test & -0.268 & 0.153 \\
\hline & Thomas test & 0.361 & 0.050 \\
\hline & Toe-touch test & 0.236 & 0.209 \\
\hline & Modified Shober test & -0.127 & 0.502 \\
\hline & Lumbar curvature & 0.152 & 0.423 \\
\hline & Cervical curvature & 0.28 & 0.125 \\
\hline
\end{tabular}

Source: Department of Orthopedics and Traumatology of ISCMSP.

\section{DISCUSSION}

There are few studies in the literature that describe the clinical and radiographic characteristics of postural roundback. On the other hand, there are numerous studies that address Scheuermann's kyphosis, not only in terms of its clinical aspects, but also its radiographic and therapeutic aspects.

Several studies mention the clinical characteristics of postural roundback, such as the forward curvature of the shoulders, the anterior projection of the head, and scapular abduction. ${ }^{24,25}$ Others also cite the presence of an increase in lumbar lordosis. $3,4,6$

In the observational analysis of the posture in the sagittal plane in our study, we found $97 \%$ of the patients with anteriorization of the head, 93\% with anteriorized and internally rotated shoulders, $67 \%$ with normal knees, and 33\% with hyperextension of the knees. Regarding cervical curvature, we found that $43 \%$ of the patients had hyperlordosis, $37 \%$ were normal, and $20 \%$ had hypolordosis. In the lumbar spine we found $77 \%$ with hyperlordosis, $17 \%$ normal, and $7 \%$ with hypolordosis. One finding that attracted our attention was the presence of hyperextension of the knees in several patients, a fact not mentioned in any other study on postural roundback. In their study of postural alterations in students between the ages of 7 and 10 , Penha et $\mathrm{al}^{2}$ state that lumbar hyperlordosis and hyperextension of the knees are common postural alterations in that age group in normal children, and that this is mainly due to abdominal weakness leading to lumbopelvic imbalance.

Several authors report that postural roundback is not clinically associated with muscular retractions, 3,4,25 however in the study by Bado et $\mathrm{al}^{26}$ of 800 children and adolescents considered to be normal, all of the subjects with roundback, functional or rigid, presented retraction of the ischiotibials, although the degree of retraction varied according to the severity of the roundback. The method used to evaluate the retraction is not mentioned.

The method used to measure retraction of the ischiotibials in this study was the popliteal angle test, a method recognized in the literature and widely used in clinical practice..$^{13-15}$

The normal value of the popliteal angle varies in the literature. ${ }^{13-15}$ In our study, the average was $135^{\circ}$, with a confidence interval $(\mathrm{Cl})$ of $95 \%$ (ranging from $131^{\circ}$ to $139^{\circ}$ ). We found that the values considered normal in the literature are always higher than the average and the confidence interval in our sample. Adopting values higher than $157^{\circ 27}$ as normal, we encountered retraction of the ischiotibials in $97 \%$ of the patients, thereby agreeing with Bado et al. ${ }^{26}$

Another method used to evaluate ischiotibial retraction is the toe-touch test, ${ }^{19}$ but it is less specific because it also assesses spinal flexibility. ${ }^{20}$ In our study, the average was $16 \mathrm{~cm}$, ranging from 13 to $19 \mathrm{~cm}(\mathrm{Cl}=95 \%)$. In studies conducted with normal individuals, the average values recorded were $4 \mathrm{~cm}^{19}$ and $5 \mathrm{~cm} .{ }^{1,21}$ By adopting the value of up to $5 \mathrm{~cm}$ above the ground as normal, $93 \%$ of the patients presented positive results, which, according to the literature, indicates retraction of the ischiotibials and reduction in the flexibility of the spine.
The objective of the modified Shober test is to evaluate the flexibility of the lumbar spine. ${ }^{17,18}$ The average in this study was $7 \mathrm{~cm}$, which corresponds with the average found by Moll and Wright ${ }^{18}$ in their study of normal individuals. The $\mathrm{Cl}$ of $95 \%$ ranged from $6-7 \mathrm{~cm}$, so the value considered to be normal in the literature is included in this interval. Fifty-three percent of the patients presented values greater than or equal to $7 \mathrm{~cm}$, corresponding to normal mobility of the lumbar spine.

In our study, normal mobility of the lumbar spine was confirmed in most patients by means of the modified Shober test and, using the popliteal angle test, retraction of the ischiotibials was also confirmed in most of the patients, implying that the factor that prevented the finger from reaching the ground was the presence of ischiotibial retraction.

In regards to the existence or not of retraction of the iliopsoas muscle in patients with postural roundback, only Kendall et al ${ }^{12}$ report its existence, while Tachdjian ${ }^{4}$ stands contrary. In our study, the average found in the Thomas test, which evaluates the hip flexor muscle retraction, was $10^{\circ}\left(\mathrm{Cl}=95 \%\right.$ ranging from $7.5^{\circ}$ to $\left.12^{\circ}\right)$. The average and the $\mathrm{Cl}$ of this sample were above the value of $0^{\circ}$ considered normal. Thus, retraction of the hip flexor muscles was present in $87 \%$ of the patients, which agrees with Kendall et al. ${ }^{12}$

Only lafusco ${ }^{24}$ reports the presence of retraction in the pectoralis major and minor muscle groups. In our study, retraction of the pectoralis minor muscle occurred in $97 \%$ of the patients, while retraction of the pectoralis major occurred in none of them. The method used to evaluate these groups of muscles was qualitative, which is more subjective and prone to error. However, no other method was found in the literature that could quantitatively express the true length of the muscle.

In the literature, we found no studies related to retraction of the shoulder adductor muscle group. By applying the test that verifies retraction of this muscle group, we found an average of $6 \mathrm{~cm}$ $(\mathrm{Cl}=95 \%$, ranging from 5 to $8 \mathrm{~cm})$. The average and the $\mathrm{Cl}$ of this sample were higher than the $0 \mathrm{~cm}$ value considered normal. The presence of muscular retraction of the shoulder adductors was encountered in $93 \%$ of the patients.

In the radiographic exam, the average angle of thoracic kyphosis was $57^{\circ}\left(\mathrm{Cl}=95 \%\right.$, ranging from 54 to $\left.60^{\circ}\right)$ corroborating the findings in the literature that in postural roundback the increase in thoracic curvature is generally mild, not exceeding $60^{\circ}$. 3,4

The radiographic assessment of lumbar lordosis presented an average value of $48^{\circ}$, with $87 \%$ of the patients with values within the normal range $\left(20\right.$ to $\left.60^{\circ}\right), 13 \%$ with hypolordosis, and none with hyperlordosis, contrary to the findings in the literature that state that in postural roundback an increase in lumbar lordosis occurs as a compensatory mechanism. 3,4,10,25 It is important to note that these authors only cite the presence of an increase in lordosis, without detailing how they reached this conclusion.

In the evaluation of cervical lordosis, most patients (91\%) presented hypolordosis (an average cervical lordosis of $17^{\circ}$ ) when we compared our findings to the studies performed with normal individuals. ${ }^{23,27}$

The results of radiographic measurement showed some differences in relation to those found in the evaluation of posture. The likely explanation for this is the subjectivity of the postural evaluation, which despite the use of a plumb line and anatomical references, still ends up being a method subject to errors and variations. The physical exam is extremely important, especially the postural assessment, but the radiographic exam and the appropriate measurements taken using the Cobb method must always be performed.

We did not find any studies on the correlation between curvatures of the spine in the sagittal plane in postural roundback, as it is very little studied in normal patients. Hardacker et $\mathrm{a}^{27}$ studied 100 normal volunteers and found that thoracic sagittal alignment is strongly correlated with changes in cervical and lumbar alignment, but Vedantan et $\mathrm{al}^{28}$ found no correlation between thoracic kyphosis and lumbar lordosis. In our study, when we correlated thoracic curvature with the other curvatures of the spine in the 
sagittal plane, we did not find a significant correlation. This indicates that the increase in thoracic curvature did not lead to an increase in lumbar curvature, and consequently to cervical curvature, as had been expected.

When we correlated the magnitude of the thoracic curvature with the ischiotibial retraction tests, such as the popliteal angle test and the toe-touch test, we did not find a significant result and thus, could not confirm our initial hypothesis. The ischiotibial retraction is probably related to the severity of the roundback in terms of rigidity of the curve as stated by Bado et al. ${ }^{26}$

A significant correlation was found only between the modified Shober test and lumbar curvature, indicating that the greater the mobility of the lumbar spine, the greater the magnitude of the lumbar curvature.

\section{CONCLUSIONS}

In postural roundback there is an increase in thoracic kyphosis. Lumbar and cervical curvatures do not increase as a compensatory mechanism. The head is anteriorized and the shoulders are anteriorized and rotated internally. There is retraction of the ischiotibial, iliopsoas, pectoralis minor, and shoulder adductor muscles. The mobility of the lumbar spine is preserved and there is no relationship between the magnitude of the thoracic curvature and the retraction of the ischiotibial muscles.

All authors declare no potential conflict of interest concerning this article.

\section{REFERENCES}

1. Garcia PLR, Medina FS, Fernandez MD, Jordana MC, Piñera JF, Marin JB. Diferencias entre la percepción de la extensibilidad muscular y el conocimiento de las dasalineaciones del raquis en el plano sagital. [Internet]. [citado 2007 jul 28]. Disponível em: http://www. um.es/univefd/Percepcion.pdf

2. Penha PJ, João SM, Casarotto RA, Amino CJ, Penteado DC. Postural assessment of girls between 7 and 10 years of age. Clinics (Sao Paulo). 2005;60(1):9-16.

3. Bradford DS. Juvenile kyphosis. In: Bradford DS, Lonstein JE, Moe JH, Ogilvie JW, Winter RB, editors. Moe's text book of scoliosis and others spinal deformities. 2nd ed. Philadelphia: Saunders; 1987. p. 347-69.

4. Tachdjan MO. Cifose juvenil de Scheuermann. In: Tachdjian MO. Pediatric Orthopedics. 2nd ed. Philadelphia: Saunders; 1990. p. 2399-409.

5. Gavin TM. The etiology and natural history of Scheuermann's Kyphosis. J Prosthet Orthotics. 2003;15(4):11-4.

6. Bonetti CL, Basile Junior R, Fazzi A. Cifose do adolescente. In: 10 Curso sobre Ortopedia Pediátrica. São Paulo: Instituto de Ortopedia e Traumatologia; 1991.

7. Carlson JM. Clinical biomechanics of orthotic treatment of thoracic hyperkyphosis. J Prosthet Orthot. 2003:15(4):31-5.

8. Bernhardt $\mathrm{M}$, Bridwell $\mathrm{KH}$. Segmental analysis of the sagittal plane alignment of the normal thoracic and lumbar spines and thoracolumbar junction. Spine (Phila Pa 1976). 1989;14(7):717-21.

9. Bradford DS, Moe JH, Winter RB. Kyphosis and postural roundback deformity in children and adolescents. Minn Med. 1973;56(2):114-20.

10. Murray PM, Weinstein SL, Spratt KF.The natural history and long-term follow-up of Scheuermann kyphosis. J Bone Joint Surg Am. 1993;75(2):236-48.

11. Loder RT. The sagittal profile of the cervical and lumbosacral spine in Scheuermann thoracic kyphosis. J Spinal Disord. 2001;14(3):226-31.

12. Kendall FP, McCreary EK. Provance PG, editors. Muscle: testing and function. 4th ed. Baltimore: Williams \& Wilkins; 1993.

13. Reimers $\mathrm{J}$. Contracture of the hamstrings in spastic cerebral palsy. A study of three methods of operative correction. J Bone Joint Surg Br. 1974;56(1):102-9.
14. Affonso Filho AA, Navarro RD. Avaliação do ângulo poplíteo em joelhos de adolescentes assintomáticos. Rev Bras Ortop. 2002;37(10):461-6.

15. Kuo L, Chung W, Bates E, Stephen J. The hamstring index. J Pediatr Orthop. 1997:17(1):78-88.

16. Tribastone F. O dorso curvo infantil. In: Tribastone F. Tratado de exercícios corretivos aplicados à reeducação motora postural. São Paulo: Manole; 2001. p. 167-71.

17. Macrae IF, Wright V. Measurement of back movement. Ann Rheum Dis. 1969;28(6):584-9.

18. Moll JM, Wright V. Normal range of spinal mobility. An objective clinical study. Ann Rheum Dis. 1971;30(4):381-6.

19. Kippers V, Parker AW. Toe-touch test. A measure of its validity. Phys Ther. 1987:67(11):1680-4

20. Perret C, Poiraudeau S, Fermanian J, Colau MM, Benhamou MA, Revel M. Validity reliability, and responsiveness of the fingertip-to-floor test. Arch Phys Med Rehabil. 2001;82(11):1566-70.

21. Mangione P, Sénégas J. Sagittal balance of the spine. Rev Chir Orthop Reparatrice Appar Mot. 1997:83(1):22-32.

22. Cobb JR. Outline for the study of scoliosis. Instr Course Lect AAOS. 1948:5:261-75.

23. Harrison DD, Janik TJ, Troyanovich SJ, Holland B. Comparisons of lordotic cervical spine curvatures to a theoretical ideal model of the static sagittal cervical spine. Spine (Phila Pa 1976). 1996;21(6):667-75

24. lafusco F. Predisposition to the round back in relation to the phases of growth. Pediatria (Napoli). 1975:83(4):646-61.

25. Negri V, Marenghi P. Juvenile kyphosis] Acta Biomed Ateneo Parmense. 1984;55(2):113-8

26. Bado JL, Barros PC, Ruggiero A, Navillat M. statistical analysis of the incidence of the retraction syndrome of the ischiotibial muscles studied in healthy infant groups and its relation to kyphosis. An Fac Med Univ Repub Montev Urug. 1964:49:328-37.

27. Hardacker JW, Shuford RF, Capicotto PN, Pryor PW. Radiographic standing cervical segmental alignment in adult volunteers without neck symptoms. Spine (Phila Pa 1976) 1997:22(13):1472-80.

28. Vedantam R, Lenke LG, Keeney JA, Bridwell KH. Comparison of standing sagittal spinal alignment in asymptomatic adolescents and adults. Spine (Phila Pa 1976). 1998;23(2):211-5. 